\title{
Liberalism, Torture, and the Ticking Bomb
}

David Luban

Georgetown University Law Center, luband@law.georgetown.edu

Copyright 2005 by the Virginia Law Review Association; Reprinted by permission of the Virginia Law Review Association.

This paper can be downloaded free of charge from:

https://scholarship.law.georgetown.edu/facpub/148

91 VA. L. Rev. 1425-1461 (2005)

This open-access article is brought to you by the Georgetown Law Library. Posted with permission of the author. Follow this and additional works at: https://scholarship.law.georgetown.edu/facpub

Part of the Human Rights Law Commons, and the Law and Society Commons 


\section{GEORGETOWN LAW Faculty Publications}

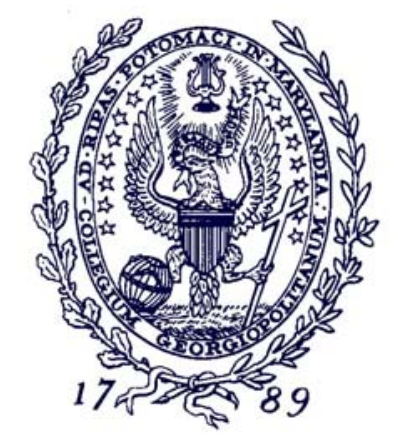

January 2010

\section{Liberalism, Torture, and the Ticking Bomb*}

91 Va. L. Rev. 1425-1461 (2005)

\section{David Luban}

Professor of Law

Georgetown University Law Center

$\underline{\text { luband@law.georgetown.edu }}$

This paper can be downloaded without charge from:

Scholarly Commons: http://scholarship.law.georgetown.edu/facpub/148/

Posted with permission of the author

* Copyright 2005 by the Virginia Law Review Association; Reprinted by permission of the Virginia Law Review Association. 


\title{
LIBERALISM, TORTURE, AND THE TICKING BOMB
}

\author{
David Luban*
}

\section{INTRODUCTION}

7 ORTURE used to be incompatible with American values. Our 1 Bill of Rights forbids cruel and unusual punishment, and that has come to include all forms of corporal punishment except prison and death by methods purported to be painless. Americans and our government have historically condemned states that torture; we have granted asylum or refuge to those who fear it. The Senate ratified the Convention Against Torture, Congress enacted antitorture legislation, and judicial opinions spoke of "the dastardly and totally inhuman act of torture."

Then came September 11. Less than one week later, a feature story reported that a quiz in a university ethics class "gave four choices for the proper U.S. response to the terrorist attacks: A.) execute the perpetrators on sight; B.) bring them back for trial im the United States; C.) subject the perpetrators to an international tribunal; or D.) torture and interrogate those involved."2 Most students chose $A$ and $D$-execute them on sight and torture them. Six weeks after September 11, the press reported that frustrated FBI interrogators were considering harsh interrogation tactics; ${ }^{3}$ a few weeks after that, the New York Times reported that torture had become a topic of conversation "in bars, on commuter trains, and

"Frederick J. Haas Professor of Law and Philosophy, Georgetown University Law Center. I have presented versions of this Essay to the Amintaphil (American section of the International Society for Legal Philosophy) conference, and at Georgetown University Law Center, Princeton University's Woodrow Wilson School, the United States Military Academy, Vanderbilt Law School, and Washington University Law School. I am grateful to the many students and colleagues participating in these presentations for their many valuable comments and probing questions. I would also like to thank the members of the Law of Torture Listserv, whose comments, encouragement, and knowledge have made the Essay far better. Finally, I wish to thank Paul Kahn and Mike Seidman, who have argued with me every step of the way.

${ }^{1}$ See, e.g., Filartiga v. Pena-lrala, 630 F.2d 876, 883 (2d Cir. 1980).

${ }^{2}$ Amy Argetsinger, At Colleges, Students Are Facing A Big Test, Wash. Post, Sept. 17,2001 , at B1.

${ }^{3}$ See, e.g., Walter Pincus, Silence of 4 Terror Probe Suspects Poses Dilemma for FBI, Wash. Post, Oct. 21, 2001, at A6. 
at dinner tables."4 By mid-November 2001, the Christian Science Monitor found that thirty-two percent of surveyed Americans favored torturing terror suspects. ${ }^{5}$ Alan Dershowitz reported in 2002 that "[d]uring numerous public appearances since September 11, 2001, I have asked audiences for a show of hands as to how many would support the use of nonlethal torture in a ticking-bomb case. Virtually every hand is raised." American abhorrence to torture now appears to have extraordinarily shallow roots.

To an important extent, one's stance on torture runs independent of progressive or conservative ideology. Alan Dershowitz suggests that torture should be regulated by a judicial warrant requirement. ${ }^{7}$ Liberal Senator Charles Schumer has publicly rejected the idea "that torture should never, ever be used." $\mathrm{He}$ argues that most U.S. senators would back torture to find out where a ticking time bomb is planted. By contrast, William Safire, a self-described "conservative ... and card-carrying hard-liner[]," expresses revulsion at "phony-tough" pro-torture arguments, and forthrightly labels torture "barbarism." Examples like these illustrate how vital it is to avoid a simple left-right reductionism. For the most part, American conservatives belong no less than progressives to liberal culture, broadly understood. Henceforth, when I speak of "liberalism," I mean it in the broad sense used by political philosophers from John Stuart Mill on, a sense that includes conservatives as well as progressives, so long as they believe in limited government and the importance of human dignity and individual rights.

My aim in this Essay is threefold. First, in Parts I and II, I will examine the place of torture within liberalism. I hope to demonstrate that there are reasons that liberals find torture peculiarly abhorrent to their political outlook-but also reasons why liberal revulsion toward torture may be only skin deep. On its surface,

\footnotetext{
${ }^{4}$ Jim Rutenberg, Torture Seeps Into Discussion By News Media, N.Y. Times, Nov. 5,2001 , at C1.

${ }^{s}$ Abraham McLaughlin, How Far Americans Would Go to Fight Terror, Christian Sci. Monitor (Boston), Nov. 14, 2001, at 1.

${ }^{6}$ Alan M. Dershowitz, Why Terrorism Works 150 (2002).

${ }^{7}$ Id. at $158-61$.

${ }^{8}$ Federal Government's Counterterrorism Efforts: Hearing Before the S. Judiciary Subcommittee, 108th Cong. (2004) (statement of Sen. Charles Schumer, Member, S. Judiciary Committee).

${ }^{9}$ William Safire, Seizing Dictatorial Power, N.Y. Times, Nov. 15, 2001, at A31.
} 
liberal reverence for individual rights makes torture morally unacceptable; at a deeper level, the same liberal ideas seemingly can justify interrogational torture in the face of danger. These ideas allow us to construct a liberal ideology of torture, by which liberals reassure themselves that essential interrogational torture is detached from its illiberal roots. The liberal ideology of torture is expressed perfectly in so-called "ticking-bomb hypotheticals" designed to show that even perfectly compassionate liberals (like Senator Schumer) might justify torture to find the ticking bomb.

Second, I will criticize the liberal ideology of torture and suggest that ticking-bomb stories are built on a set of assumptions that amount to intellectual fraud (Parts III and IV). Ticking-bomb stories depict torture as an emergency exception, but use intuitions based on the exceptional case to justify institutionalized practices and procedures of torture. In short, the ticking bomb begins by denying that torture belongs to liberal culture, and ends by constructing a torture culture.

My third aim in the Essay is to illustrate these dialectical adventures of the liberal ideology of torture through a case study of the executive-branch lawyers who solicited or wrote memoranda justifying some cases of official brutality (Part V). ${ }^{10}$ The result, I believe, will be a perfect example of how a secretive torture culture emerges from the liberal ideology of torture-a disquieting illustra-

\footnotetext{
${ }^{10}$ Most of the memoranda, Abu Ghraib related reports, and other essential documents dealing with U.S. interrogation pohcy, torture, and treatment of detainees have been assembled in The Torture Papers: The Road to Abu Ghraib (Karen J. Greenberg \& Joshua L. Dratel eds., 2005) [hereinafter Torture Papers]. A smaller collection of torture papers, including many of the Abu Ghraib photographs and an astute analysis, has also appeared. Mark Danner, Torture and Truth: America, Abu Ghraib, and the War on Terror (2004). Both collections include the memorandum dated August 1, 2002, which I shall refer to as the "Bybee Memorandum" or "Bybee Memo" (because it went out over the signature of Jay S. Bybee, although its principal author was apparently John C. Yoo). Memorandum from Jay S. Bybee, Assistant Attorney Gen., U.S. Dep't of Justice, to Alberto R. Gonzales Counsel to the President (Aug. 1, 2002), reprinted in Torture Papers, supra, at 172, and in Danner, supra, at 115. But in fact, the 1,249-page Torture Papers was out of date before it was printed in January 2005: The Bybee Memo was replaced on December 30, 2004, and new information and memoranda have leaked out intermittently ever since. A second volume of torture papers is currently under preparation.

Many arguments in the debate about torture appear in the superb anthology Torture: A Collection (Sanford Levinson ed., 2004).
} 
tion of how liberalism deals with the unpleasant question of torture.

\section{PutTing CRUElTy First}

Unhappily, torture is as old as human history. Montaigne once wrote, "[n]ature herself, I fear, attaches to man some instinct for inhumanity." That sounds right. Most children at some point entertain sadistic fantasies, and many act them out. Infantile sadism may actually be an essential stage in the process of differentiating self from other and acquiring physical agency in the external world: "I can pinch and I feel nothing, but you or she or the cat yelps in pain; I am not you or her or the cat; and it's fun making you or her or the cat notice me." Causing pain in others allows the child to learn that some of the objects around him are subjects with feelings of their own, and in this way, bouts of infantile sadism may be essential to developing adult empathy. But, while infantile sadism may be essential for human development, eventually torture fantasies must be repressed. To be sure, sadism persists in some people's erotic lives. But apart from consensual bedroom behavior, liberal societies condemn torture as a serious and depraved form of battery.

Yet the modern liberal's revulsion toward torture is unusual. As Nietzsche and Foucault remind us, through most of human history there was no taboo on torture in military and juridical contexts, and so no need to repress the infantile sadism that nature has bequeathed us. ${ }^{12}$ Indeed, Judith Shklar notes a remarkable fact, namely that cruelty did not seem to figure in classical moral thought as an important vice: "[O]ne looks in vain for a Platonic dialogue on cruelty. Aristotle discusses only pathological bestiality, not cruelty. Cruelty is not one of the seven deadly sins .... The many manifestations of cupidity seem, to Saint Augustine, more

\footnotetext{
${ }^{11}$ Michel de Montaigne, Of cruelty, in The Complete Essays of Montaigne 306, 316 (Donald M. Frame trans., 1958) (1580).

${ }^{12}$ Both Nietzsche and Foucault describe torture as a festive occasion. See Friedrich Nietzsche, On the Genealogy of Morals, in Basic Writings of Nietzsche 439, 501-03 (Walter Kaufmann ed. \& trans., 1968) (1887) ("Without cruelty there is no festival ...."); MicheI Foucault, Discipline and Punish: The Birth of the Prison 8 (Alan Sheridan trans., Vintage Books 1979) (1975) (describing "the gloomy festival of punishment").
} 
important than cruelty."13 It is only in relatively modern times, Shklar thinks, that we have come to "put cruelty first"- that is, regard it as the most vicious of all vices. ${ }^{14}$ She thinks that Montaigne and Montesquieu, both of them proto-liberals, were the first political philosophers to think this way; and, more generally, she holds that "hating cruelty, and putting it first [among vices], remain a powerful part of the liberal consciousness." ${ }^{15}$ Shklar also observes that putting cruelty first, as liberals do, incurs genuine moral costs: "It makes political action difficult beyond endurance, may cloud our judgment, and may reduce us to a debilitating misanthropy ....".16

Perhaps these difficulties account for the ease with which we abandoned our reluctance to torture in the aftermath of $9 / 11$. But I believe there are indeed reasons why torture and cruelty are particularly incompatible with liberalism. And, as I hope to show, one way this incompatibility manifests itself is through arguments designed to show that torturing terrorists for information is not done out of cruelty.

\section{THE FIVE AIMS OF TORTURE}

What makes torture, the deliberate infliction of suffering and pain, especially abhorrent to liberals? This may seem like a bizarre question, because the answer seems self-evident: making people suffer is a horrible thing. Pain hurts and bad pain hurts badly. But let me pose the question in different terms. Realistically, the abuses of detainees at Abu Ghraib, Baghram, and Guantanamo pale by comparison with the death, maiming, and suffering in collateral damage during the Afghan and Iraq wars. Bombs crush limbs and burn people's faces off; nothing even remotely as horrifying has been reported in American prisoner abuse cases. Yet as much as we may regret or in some cases decry the wartime suffering of innocents, we do not seem to regard it with the special abhorrence that we do torture. This seems hypocritical and irrational, almost fetishistic, and it raises the question of what makes torture

\footnotetext{
${ }^{13}$ Judith N. Shklar, Ordinary Vices 7 (1984).

${ }^{14}$ Id. at 8.

${ }^{15}$ Id. at 43.

${ }^{16}$ Id.
} 
more illiberal than bombing and killing. ${ }^{17}$ The answer lies in the relationship between torturer and victim. The self-conscious aim of torture is to turn its victim into someone who is isolated, overwhelmed, terrorized, and humiliated. Torture aims to strip away from its victim all the qualities of human dignity that liberalism prizes. The torturer inflicts pain one-on-one, deliberately, up close and personal, in order to break the spirit of the victim-in other words, to tyrannize and dominate the victim. The relationship between them becomes a perverse parody of friendship and intimacy: intimacy transformed into its inverse image, where the torturer focuses on the victim's body with the intensity of a lover, except that every bit of that focus is bent to causing pain and tyrannizing the victim's spirit. ${ }^{18}$

I am arguing that torture is a microcosm, raised to the highest level of intensity, of the tyrannical political relationships that liberalism hates the most. I have said that torture isolates and privatizes. Pain forcibly severs our concentration on anything outside of us; it collapses our horizon to our own body and the damage we feel in it. Even much milder sensations of prolonged discomfort can distract us so much that it becomes impossible to pay attention to anything else, as anyone knows who has had to go to the bathroom in a situation where it cannot be done. Ludwig Wittgenstein wrote that the world of the happy is different from the world of the

\footnotetext{
${ }^{17}$ I have heard this argument from several people, but Paul Kahn and Mike Seidman have pressed it on me most compellingly in conversation.

${ }^{18}$ My point here is somewhat different from that of Henry Shue, who examines the argument that since killing is worse than torture, and killing is permitted in warfare, torture might be as well. Shue argues that in warfare, there is a kind of reciprocity between combatants, who place each other mutually at risk, whereas torture is more like killing the defenseless. Henry Shue, Torture, 7 Phil. \& Pub. Aff. 124, 125, 129-30 (1978). I am arguing that torture is like tyrannizing the defenseless rather than killing them. David Sussman argues that the special evil in torture consists in "forc[ing] its victim into the position of colluding against himself through his own affects and emotions, so that he experiences himself as simultaneously powerless and yet actively complicit in his own violation." David Sussman, What's Wrong with Torture?, 33 Phil. \& Pub. Aff. 1, 4 (2005). The idea seems to be "that the only thing that matters to [the torture victim] is pleasing this other person who appears infinitely distant, important, inscrutable, powerful, and free." Id. at 25-26. Perhaps we experience tyranny as forcing us to collude against ourselves, in which case my argument is similar to Sussman's. But I find Sussman's image of the victim as someone "actively complicit in his own violation" rather implausible, as a description of either torture or tyranny.
} 
unhappy, ${ }^{19}$ and this is not simply a figure of speech when we suffer severe pain. The world of the man or woman in great pain is a world without relationships or engagements, a world without an exterior. It is a world reduced to a point, a world that makes no sense and in which the human soul finds no home and no repose. ${ }^{20}$

And torture terrorizes. The body in pain winces; it trembles. The muscles themselves register fear. This is rooted in pain's biological function of impelling us in the most urgent way possible to escape from the source of pain-for that impulse is indistinguishable from panic. U.S. interrogators have reportedly used the technique of "waterboarding" to break the will of detainees." Waterboarding involves immersing the victim's face in water or wrapping it in a wet towel to induce drowning sensations. As anyone who has ever come close to drowning or suffocating knows, the oxygen-starved brain sends panic signals that overwhelm everything else. You can experience suffocation-panic for yourself right now by fully exhaling and then holding your breath for thirty seconds.

And torture humiliates. It makes the victim scream and beg; the terror makes him lose control of his bowels and bladder. ${ }^{22}$ The es-

${ }^{19}$ Ludwig Wittgenstein, Tractatus Logico-Philosophicus 87 (D.F. Pears \& B.F.
McGuinness trans., Routledge Classics 2001) (1921).
${ }^{20}$ This is one of Elaine Scarry's chief points in The Body in Pain: The Making and
Unmaking of the World 33 (1985) ("As in dying and death, so in serious pain the
claims of the body utterly nullify the claims of the world."). Scarry offers perhaps the
most famous phenomenology of torture. However, as will soon become apparent, I
differ from Scarry because she thinks that torture exists only in the context of interro-
gation. Id. at 28 ("Torture consists of a primary physical act, the infliction of pain, and
a primary verbal act, the interrogation."); Id. at 29 ("Pain and interrogation inevitably
occur together...."). I subsequently argue that coupling torture with interrogation is
only one historically significant motivation for torture.

${ }^{21}$ See, e.g., Responses of Alberto R. Gonzales Nominee to be Attorney General of the United States to Written Questions of Senator Richard J. Durbin 3-5 (2005) (on file with the Virginia Law Review Association) [hereinafter Gonzales's Responses to Durbin] (posing questions about waterboarding, with evasive answers); Douglas Jehl, Questions Left By C.I.A. Chief on Torture Use, N.Y. Times, Mar. 18, 2005, at A1 (describing a question about waterboarding posed by Sen. John McCain to CIA head Porter Goss and his evasive answer); Editorial, 'Torture' Showdown, Wall St. J., Jan. 6,2005 , at A16 (describing waterboarding as "the most coercive technique that was ever actually authorized" by U.S. officials).

${ }^{22}$ The Fay-Jones Report on Abu Ghraib mentions "an alleged contest between the two Army dog handlers to see who could make the internees urinate or defecate in the presence of the dogs." LTG Anthony R. Jones \& MG George R. Fay, The FayJones Report (Aug. 2004), in Torture Papers, supra note 10, at 987, 1070 [hereinafter Fay-Jones Report]. 
sence of cruelty is inflicting pain for the purpose of lording it over someone-we sometimes say "breaking" them-and the mechanism of cruelty is making the victim the audience of your own mastery. Cruelty always aims at humiliation. One curious feature of legal procedure in both ancient Greece and Rome was a rule "that slaves were permitted to [testify in a court of law] only under torture."23 Sir Moses Finley's plausible explanation is that the rule served to mark off the absolute difference in status between slaves and even the lowliest freemen. ${ }^{24}$ The torture rule reinforces the message that slaves are absolutely subjugated. Humiliation occurs when I am low and you are high and you insist on it.

\section{Victor's Pleasure}

The predominant setting for torture has always been military victory. The victor captures the enemy and tortures him. I recently saw some spectacular Mayan murals depicting defeated enemies from a rival city-state having their fingernails torn out before being executed in a ritual reenactment of the battle.

Underneath whatever religious significance that attaches to torturing the vanquished, the victor tortures captives for the simplest of motives: to relive the victory, to demonstrate the absoluteness of his mastery, to rub the loser's face in it, and to humiliate the loser by making him scream and beg. For the victorious warrior, it's fun; it's entertainment. ${ }^{25}$ It prolongs the rush of victory. Montaigne denounced what he called "the uttermost point that cruelty can attain," namely torture "for the sole purpose of enjoying the pleasing spectacle of the pitiful gestures and movements, the lamentable

\footnotetext{
${ }^{23}$ Moses I. Finley, Ancient Slavery and Modern Ideology 162 (Markus Wiener Publishers 1998).

${ }^{24}$ Id. at 163 . I suppose that the rationale was that if a slave were permitted to testify against his own master freely, then the society would be admitting that property can freely betray its owner, a dangerous thought in slaveholding societies. Hence, the slave can only be permitted to testify under compulsion. Hannah Arendt claimed it was because the ancients believed that "nobody can invent a lie under torture," but this speculation does nothing to explain why slaves and only slaves had to be tortured. Hannah Arendt, The Human Condition 129 n.78 (2d ed. 1998).

${ }^{25}$ Nietzsche, supra note 12 , at 501 (describing "the pleasure of being allowed to vent his power freely upon one who is powerless, the voluptuous pleasure 'de faire le mal pour le plaisir de le faire', the enjoyment of violation").
} 
groans and cries, of a man dying in anguish." ${ }^{, 6}$ Even if the torturer's motives do not reach that level of cruelty, the victim's humiliation and subjugation are undeniable.

Already we can see why liberals abhor torture. Liberalism incorporates a vision of engaged, active human beings possessing an inherent dignity regardless of their social station. The victim of torture is in every respect the opposite of this vision. The torture victim is isolated and reduced instead of engaged and enlarged, terrified instead of active, humiliated instead of dignified. And, in the paradigm case of torture, the victor's torment of defeated captives, liberals perceive the living embodiment of their worst nightmare: tyrannical rulers who take their pleasure from the degradation of those unfortunate enough to be subject to their will.

There are at least four other historically significant reasons for torture besides victor's cruelty (the paradigm case), and as we shall see, all but one of them is fundamentally inimical to liberalism.

\section{Terror}

First, there is torture for the purpose of terrorizing people into submission. Dictators from Hitler to Pinochet to Saddam Hussein tortured their political prisoners so that their enemies, knowing that they might face a fate far worse than death, would be afraid to oppose them. Genghis Khan's conquests were made easier because his reputation for cruelty against those who opposed him led cities to surrender without a fight. Terror is a force-magnifier that permits a relatively small number of police to subdue a far larger population than they could if would-be rebels were confident that they would be treated humanely upon capture. But of course, a practice that exists to make it easier to subdue and tyrannize people is fundamentally hostile to liberals' political philosophy.

\section{Punishment}

Second, until the last two centuries, torture was used as a form of criminal punishment. It was torture as a form of punishment that drew Montaigne's condemnation, and it is noteworthy that the Eighth Amendment to the U.S. Constitution prohibits cruel and

\footnotetext{
${ }^{26}$ Montaigne, supra note 11 , at 316.
} 
unusual punishments, rather than cruelty more generally. Beccaria condemns punishments that are more cruel than is absolutely necessary to deter crime, arguing on classical-liberal grounds that people in the state of nature will surrender only the smallest quantum of liberty necessary to secure society: "The aggregate of these smallest possible portions of individual liberty constitutes the right to punish; everything beyond that is an abuse and not justice, a fact but scarcely a right."27 Beccaria makes it clear that torture would turn society into "a herd of slaves who constantly exchange timid cruelties with one another." 28 Such punishments, he adds, "would also be contrary to justice and to the nature of the social contract itself," 29 presumably because turning society into a herd of slaves undermines the liberal understanding of the ends of society. Beccaria was widely read in America during the founding era. ${ }^{30}$

Foucault argues that the abolition of punitive torture had little to do with increased humanitarianism. Instead, it had to do with a change in the distribution of crime in Western Europe. As the West grew more prosperous, property crimes eclipsed crimes of passion as a social problem. This led to calls for a milder but more certain system of punishments. The trouble with torture is that when the punishment is so awful, the temptation to mercy becomes too great. Imprisonment, out of sight and out of mind, replaced the public spectacle of torment. ${ }^{31}$

Be that as it may, it seems equally clear that punitive torture had no place in liberal polities. Torture, as Foucault explains, was a symbolic assertion of the absolute sovereign whose personal prerogatives had been affronted by crime. It was a ritual of royal dominance and royal revenge, acted out in public spectacle to shock and awe the multitude. ${ }^{32}$ With the growth of liberal democ-

${ }^{27}$ Cesare Beccaria, On Crimes and Punishments 8-9 (David Young trans., Hackett Publishing Co. 1986) (1764).

${ }^{28}$ Id. at 10.

${ }^{29}$ Id.

${ }^{30}$ Irene Quenzler Brown \& Richard D. Brown, The Hanging of Ephraim Wheeler: A Story of Rape, Incest, and Justice in Early America 192-94, 260-61, 264, 278 (2003) (discussing prominent Revolutionary-era figures influenced by Beccaria); Adam Jay Hirsch, The Rise of the Penitentiary: Prisons and Punishment in Early America 26 (1992) (noting Beccaria's influence in early America).

${ }^{31}$ Foucault, supra note 12 , at 82-89.

${ }^{32} \mathrm{ld}$. at $48-49$ " "It is a ceremonial by which a momentarily injured sovereignty is reconstituted. It restores that sovereignty by manifesting it at its most spectacular... . 
racy, the ideology of popular sovereignty deflated the purpose of punitive torture: if the people rule, then the responsibility of torture would fall on the people, and the need for a spectacle of suffering by which the people could impress themselves seemed pointless.

\section{Extracting Confessions}

Curiously, when Beccaria writes explicitly about the subject of torture, he does not mention torture as punishment. Rather, he polemicizes against judicial torture in order to extract confessions from criminal suspects. ${ }^{34}$ This is the third historically significant use of torture, distinct from punishment, even though judges administer both. The French language has different words for them: le supplice, torture as punishment, and la question, torture to extract confessions. As John Langbein observes, pre-modern legal rules required either multiple eyewitnesses or confessions for criminal convictions. At first glance, these were important rights of the accused, but they had the perverse effect of legitimating judicial torture in order to make convictions possible. But once it was accepted that the criminal justice system could base guilty verdicts on various types of evidence that rationally establish facts, rather than insisting on the ritual of confession, then the need for torture to secure convictions vanished. ${ }^{35}$ Furthermore, the only crimes for which the primary evidence is the perpetrator's own words are crimes of heretical or seditious belief-and liberalism rejects the criminalization of belief. ${ }^{36}$

[T]his practice of torture was . . a policy of terror: to make everyone aware, through the body of the criminal, of the unrestrained presence of the sovereign.").

${ }^{33}$ Granted, the public spectacle of suffering certainly persisted in the American practice of lynching.

${ }_{34}^{4}$ Beccaria, supra note 27 , at 29-33.

${ }^{35}$ John H. Langbein, Torture and the Law of Proof: Europe and England in the Ancien Régime, 4-5, 45-69 (1977); John H. Langbein, Torture and Plea Bargaining, 46 U. Chi. L. Rev. 3, 4-5 (1978).

${ }^{36}$ See Alan Donagan, The Right Not to Incriminate Oneself, 1 Soc. Phil. \& Pol'y $137,143-44(1984)$. 


\section{Intelligence Gathering}

These, then, are the four illiberal motives for torture: victor's pleasure, terror, punishment, and extracting confessions. That leaves only one rationale for torture that might conceivably be acceptable to a liberal: torture as a technique of intelligence gathering from captives who will not talk. This may seem indistinguishable from torture to extract confessions, because both practices couple torture with interrogation. The crucial difference lies in the fact that the confession is backward-looking, in that it aims to document and ratify the past for purposes of retribution, while intelligence gathering is forward-looking because it aims to gain information to forestall future evils like terrorist attacks.

It is striking, and in obvious ways reassuring, that this is the only rationale for torture that liberal political culture admits could even possibly be legitimate. To speak in a somewhat perverse and paradoxical way, liberalism's insistence on limited governments that exercise their power only for instrumental and pragmatic purposes creates the possibility of seeing torture as a civilized, not an atavistic, practice, provided that its sole purpose is preventing future harms. Rejecting torture as victor's spoils, as terror, as punishment, and as a device to force confession drastically limits the amount of torture that a liberal society might conceivably accept. But more importantly, the liberal rationale for torture as intelligence gathering in gravely dangerous situations transforms and rationalizes the motivation for torture. Now, for the first time, it becomes possible to think of torture as a last resort of men and women who are profoundly reluctant to torture. And in that way, liberals can for the first time think of torture dissociated from cruelty-torture authorized and administered by decent human beings who abhor what circumstances force them to do. Torture to gather intelligence and save lives seems almost heroic. For the first time, we can think of kindly torturers rather than tyrants.

I shall be arguing shortly that this way of thinking represents a dangerous delusion. But before abandoning the subject of how torture "became civilized," it is important to note one other dimension in which torture has become less cruel.

Readers of Foucault's Discipline and Punish will probably never forget its nauseating opening pages, in which Foucault describes in loving detail the gruesome death by torture of the man who as- 
saulted Louis XV. ${ }^{37}$ Foucault aims to shock, of course, and he certainly succeeded with me: I closed the book and would not open it again for twenty years. There is a vast difference, however, between the ancient world of torture, with its appalling mutilations, its roastings and flayings, and the tortures that liberals might accept: sleep deprivation, prolonged standing in stress positions, extremes of heat and cold, bright lights and loud music-what some refer to as "torture lite."

I do not mean to diminish how horrible these experiences are, nor do I mean to suggest that American interrogators never go further than torture lite. Waterboarding, withholding of pain medication from wounded captives, putting lit cigarettes in their ears, rape, and beatings all go much further. ${ }^{38}$ At least five, and maybe more than twenty captives have been beaten to death by American interrogators. ${ }^{39}$ My point is rather that liberals generally draw the

\footnotetext{
${ }^{37}$ Foucault, supra note 12 , at 3-6.

${ }^{38}$ The Fay-Jones Report mentions alleged sodomy of a detainee with a police stick. Fay-Jones Report, supra note 22, at 1076. A memorandum to FBI officials reported the placing of lit cigarettes into detainees' ears at Guantanamo. See Neil A. Lewis \& David Johnston, New F.B.I. Files Describe Abuse Of Iraq Inmates, N.Y. Times, Dec. 21,2004 , at A1. For that matter, there need be nothing "lite" about "torture lite." An FBI agent wrote:
}

On another occasion, the $\mathrm{A} / \mathrm{C}$ had been turned off, making the temperature in the unventilated room probably well over 100 degrees. The detainee was almost unconscious on the floor, with a pile of hair next to him. He had apparently been literally pulling his own hair out throughout the night.

Id. (internal quotations omitted). The withholding of pain medication and waterboarding or other faux-suffocation techniques reportedly have been admitted by U.S. officials in the interrogation of Abu Zubaidah and Khalid Sheik Mohammed. See, e.g., Douglas Jehl \& David Johnston, C.I.A. Expands Its Inquiry Into Interrogation Tactics, N.Y. Times, Aug. 29, 2004, at A10; Dana Priest, CIA Puts Harsh Tactics on Hold, Wash. Post, June 27, 2004, at A1; Susan Schmidt, Disclosure of Authorized Interrogation Tactics Urged, Wash. Post, July 3, 2004, at A3.

${ }^{39}$ In July 2004, an Army investigation of detainee operations in Iraq and Afghanistan uncovered ninety-four cases of alleged abuse, including thirty-nine deaths in U.S. custody. Twenty of the deaths were suspected homicides. Craig Pyes \& Mark Mazzetti, U.S. Probing Alleged Abuse of Afghans, L.A. Times, Sept. 21, 2004, at A1. The military has reportedly investigated, or is investigating, fifty-eight deaths in Iraq, which include nine cases of justifiable homicide, seven homicides, and twentyone deaths from natural or undetermined causes. Demetri Sevastopulo, Two More Soldiers Charged with Homicide, Financial Times Asia, Sept. 29, 2004.

In one case of a detainee death, several soldiers have been charged with abuse rather than homicide due to insufficient evidence. In another case, two soldiers were charged with premeditated murder. Eric Schmitt, Navy Charges 3 Commandos With Beating Of Prisoners, N.Y. Times, Sept. 25, 2004, at A7. Army investigators have rec- 
line at forms of torture that maim the victim's body. This, like the limitation of torture to intelligence gathering, marks an undeniable moderation in torture, the world's most immoderate practice. It's almost enough to persuade us that torture lite is not torture at all, or at least that it isn't cruel enough to make liberals wince, at least not when the stakes are sufficiently high. Indeed, they may even deny that it is torture.

Let me summarize this part of my argument. Liberals, I have said, rank cruelty first among vices-not because liberals are more compassionate than anyone else, but because of the close connection between cruelty and tyranny. Torture is the living manifestation of cruelty, and the peculiar horror of torture within liberalism arises from the fact that torture is tyranny in microcosm, at its highest level of intensity. The history of torture reinforces this horror because torture has always been bound up with military conquest, regal punishment, dictatorial terror, forced confessions, and the repression of dissident belief - a veritable catalogue of the evils of absolutist government that liberalism abhors. For all these reasons, it should hardly surprise us that liberals wish to ban torture

ommended that at least three Army Reserve soldiers be charged with negligent homicide for their role in the beating death of two prisoners in a Bagram detention facility outside of Kabul. Tom Bowman, Charges Urged in Deaths of Detainees, Balt. Sun, Sept. 16, 2004, at A1. Two marines were charged with negligent homicide in relation to the death of Nagem Sadoon Hatab in the Camp Whitehorse detention center outside Nasiriyah. The charges against one of the marmes were eventually dropped. Deborah Hastings, Iraq POW Death Remains a Mystery, Times Union (Albany, N.Y.), Aug. 1, 2004, at A2. And a Navy SEAL, whose identity has not been released, is being court-martialed in connection with the beating of Manadel Jamadi, who was later killed, allegedly by CIA interrogators, in Abu Ghraib (and who was photographed there, packed in ice). Schmitt, supra, at A7; Court-Martial of Navy SEAL in Abuse of Iraqi Postponed, Wash. Post, Mar. 22, 2005, at A18. According to an independent panel's report on Abu Ghraib, there have been "five cases of detainee deaths as a result of abuse by U.S. personnel during interrogations" already substantiated. Final Report of the Independent Panel To Review DOD Detention Operations (Aug. 2004), in Torture Papers, supra note 10, at 908, 914 [hereinafter Schlesinger Report]. Yet a more recent account reports that "[a]t least 26 prisoners have died in American custody in Iraq and Afghanistan since 2002 in what Army and Navy investigators have concluded or suspect were acts of criminal homicide, according to military officials." Douglas Jehl \& Eric Schmitt, U.S. Military Says 26 Inmate Deaths May Be Homicide, N.Y. Times, Mar. 16, 2005, at A1. 
absolutely-a wish that became legislative reality in the Torture Convention's insistence that nothing can justify torture. ${ }^{40}$

But what about torture as intelligence gathering, torture to forestall greater evils? I suspect that throughout history this has been the least common motivation for torture, and thus the one most readily overlooked. And yet it alone bears no essential connection with tyranny. This is not to say that the torture victim experiences it as any less terrifying, humiliating, or tyrannical. The victim, after all, undergoes abject domination by the torturer. But it will dawn on reluctant liberals that the torturer's goal of forestalling greater evils is one that liberals share. It seems like a rational motivation, far removed from cruelty and power-lust. In fact, the liberal may for the first time find it possible to view torture from the torturer's point of view rather than the victim's.

Thus, even though absolute prohibition remains liberalism's primary teaching about torture, and the basic liberal stance is empathy for the torture victim, a more permissive stance remains an unspoken possibility, the Achilles' heel of absolute prohibitions. As long as the intelligence needs of a liberal society are slight, this possibility within liberalism remains dormant, perhaps even unnoticed. But when a catastrophe like 9/11 happens, liberals may cautiously conclude that, in the words of a well-known Newsweek article, it is "Time to Think About Torture."

But the pressure of liberalism will compel them to think about it in a highly stylized and artificial way, what I will call the "liberal ideology of torture." The liberal ideology insists that the sole purpose of torture must be intelligence gathering to prevent a catastrophe; that torture is necessary to prevent the catastrophe; that torturing is the exception, not the rule, so that it has nothing to do with state tyranny; that those who inflict the torture are motivated solely by the looming catastrophe, with no tincture of cruelty; that torture in such circumstances is, in fact, little more than selfdefense; and that, because of the associations of torture with the

${ }^{40}$ "No exceptional circumstances whatsoever, whether a state of war or a threat of war, internal political instability or any other public emergency, may be invoked as a justification of torture." Convention Against Torture and Other Cruel, Inhuman or Degrading Treatment or Punishment, art. 2, Mar. 4, 1984, S. Treaty Doc. No. 100-20, 1465 U.N.T.S. 85, 114 [hereinafter Convention Against Torture].

${ }^{41}$ Jonathan Alter, Time to Think About Torture, Newsweek, Nov. 5, 2001, at 45, 45. 
horrors of yesteryear, perhaps one should not even call harsh interrogation "torture."

And the liberal ideology will crystallize all of these ideas in a single, mesmerizing example: the ticking time bomb.

\section{THE TICKING BOMB}

Suppose the bomb is planted somewhere in the crowded heart of an American city, and you have custody of the man who planted it. He won't talk. Surely, the hypothetical suggests, we shouldn't be too squeamish to torture the information out of him and save hundreds of lives. Consequences count, and abstract moral prohibitions must yield to the calculus of consequences.

Everyone argues the pros and cons of torture through the ticking time bomb. Senator Schumer and Professor Dershowitz, the Israeli Supreme Court and indeed every journalist devoting a think-piece to the unpleasant question of torture, begins with the ticking time bomb and ends there as well. The Schlesinger Report on Abu Ghraib notes that "[f]or the U.S., most cases for permitting harsh treatment of detainees on moral grounds begin with variants of the 'ticking time-bomb' scenario." ${ }^{, 42}$ At this point in my argument, I mean to disarm the ticking time bomb and argue that it is the wrong thing to think about. If so, then the liberal ideology of torture begins to unravel.

But before beginning these arguments, I want to pause and ask why this jejune example has become the alpha and omega of our thinking about torture. I believe the answer is this: The ticking time bomb is proffered against liberals who believe in an absolute prohibition against torture. The idea is to force the liberal prohibitionist to admit that yes, even he or even she would agree to torture in at least this one situation. Once the prohibitionist admits that, then she has conceded that her opposition to torture is not based on principle. Now that the prohibitionist has admitted that her moral principles can be breached, all that is left is haggling about the price. No longer can the prohibitionist claim the moral high ground; no longer can she put the burden of proof on her opponent. She is down in the mud with them, and the only question left is how much further down she will go. Dialectically, getting the

\footnotetext{
${ }^{42}$ Schlesinger Report, supra note 39, at 908, 974.
} 
prohibitionist to address the ticking time bomb is like getting the vegetarian to eat just one little oyster because it has no nervous system. Once she does that-gotcha!

The ticking time-bomb scenario serves a second rhetorical goal, one that is equally important to the proponent of torture. It makes us see the torturer in a different light-one of the essential points in the liberal ideology of torture because it is the way that liberals can reconcile themselves to torture even while continuing to "put cruelty first." Now, he is not a cruel man or a sadistic man or a coarse, insensitive brutish man. The torturer is instead a conscientious public servant, heroic the way that New York firefighters were heroic, willing to do desperate things only because the plight is so desperate and so many innocent lives are weighing on the public servant's conscience. The time bomb clinches the great divorce between torture and cruelty; it placates liberals, who put cruelty first.

Wittgenstein once wrote that confusion arises when we become bewitched by a picture. ${ }^{43}$ He meant that it's easy to get seduced by simplistic examples that look compelling but actually misrepresent the world in which we live. If the subject is the morality of torture, philosophical confusions can have life-or-death consequences. I believe the ticking time bomb is the picture that bewitches us.

I don't mean that the time-bomb scenario is completely unreal. To take a real-life counterpart: in 1995, an al Qaeda plot to bomb eleven U.S. airliners and assassinate the Pope was thwarted by information tortured out of a Pakistani bomb-maker by the Philippine police. ${ }^{44}$ According to journalists Marites Dañguilan Vitug and Glenda M. Gloria, the police had received word of possible threats against the Pope. They went to work. "For weeks, agents hit him with a chair and a long piece of wood, forced water into his mouth, and crushed lighted cigarettes into his private parts.... His ribs were almost totally broken that his captors were surprised that he

\footnotetext{
${ }^{43}$ Ludwig Wittgenstein, Philosophical Investigations $47 e-48$ e (G.E.M. Anscombe trans., 3d ed. 1958).

${ }^{44}$ Doug Struck et al., Borderless Network Of Terror: Bin Laden Followers Reach Across Globe, Wash. Post, Sept. 23, 2001, at A1.
} 
survived . ..." ${ }^{, 45}$ Grisly, to be sure-but if they hadn't done it, thousands of innocent travelers might have died horrible deaths.

But look at the example one more time. The Philippine agents were surprised he survived-in other words, they came close to torturing him to death before he talked. And they tortured him for weeks, during which time they didn't know about any specific al Qaeda plot. What if he too didn't know? Or what if there had been no al Qaeda plot? Then they would have tortured him for weeks, possibly tortured him to death, for nothing. For all they knew at the time, that is exactly what they were doing. You cannot use the argument that preventing the al Qaeda attack justified the decision to torture, because at the moment the decision was made no one knew about the al Qaeda attack.

The ticking-bomb scenario cheats its way around these difficulties by stipulating that the bomb is there, ticking away, and that officials know it and know they have the man who planted it. Those conditions will seldom be met. ${ }^{46}$ Let us try some more realistic hypotheticals and the questions they raise:

1. The authorities know there may be a bomb plot in the offing, and they have captured a man who may know something about it, but may not. Torture him? How much? For weeks? For months? The chances are considerable that you are torturing a man with nothing to tell you. If he doesn't talk, does that mean it's time to stop, or time to ramp up the level of torture? How likely does it have to be that he knows something important? Fifty-fifty? Thirtyseventy? Will one out of a hundred suffice to land him on the waterboard?

\footnotetext{
${ }^{45}$ Marites Dañguilan Vitug \& Glenda M. Gloria, Under the Crescent Moon: Rebellion in Mindanao 223 (2000).

${ }^{46}$ See Oren Gross, Are Torture Warrants Warranted? Pragmatic Absolutism and Official Disobedience, 88 Minn. L. Rev. 1481, 1501-03 (2004). Gross reminds us, however, that the catastrophic case can actually occur. Id. at 1503-04. The tickingbomb case might occur if a government has extremely good intelligence about a terrorist group-good enough to know that it has dispatched operatives to carry out an operation, and good enough to identify and capture someone in the group who knows the details-but not good enough to know the details without getting them from the captive. Israel seems like a setting in which cases like this might arise, and indeed, Mark Bowden reports on just such a case. Mark Bowden, The Dark Art of Interrogation, Atlantic Monthly, Oct. 2003, at 51, 65-68. Importantly, however, the Israeli interrogator obtained the information through trickery, not torture.
} 
2. Do you really want to make the torture decision by running the numbers? A one-percent chance of saving a thousand lives yields ten statistical lives. Does that mean that you can torture up to nine people on a one-percent chance of finding crucial information?

3. The authorities think that one out of a group of fifty captives in Guantanamo might know where Osama bin Laden is hiding, but they do not know which captive. Torture them all? That is: Do you torture forty-nine captives with nothing to tell you on the uncertain chance of capturing bin Laden?

4. For that matter, would capturing Osama bin Laden demonstrably save a single human life? The Bush administration has downplayed the importance of capturing bin Laden because American strategy has succeeded in marginalizing him. Maybe capturing him would save lives, but how certain do you have to be? Or does it not matter whether torture is intended to save human lives from a specific threat, as long as it furthers some goal in the War on Terror? This last question is especially important once we realize that the interrogation of al Qaeda suspects will almost never be employed to find out where the ticking bomb is hidden. Instead, interrogation is a more general fishing expedition for any intelligence that might be used to help "unwind" the terrorist organization. Now one might reply that al Qaeda is itself the ticking time bomb, so that unwinding the organization meets the formal conditions of the ticking-bomb hypothetical. This is equivalent to asserting that any intelligence that promotes victory in the War on Terror justifies torture, precisely because we understand that the enemy in the War on Terror aims to kill American civilians. Presumably, on this argument, Japan would have been justified in torturing American captives in World War II on the chance of finding intelligence that would help them shoot down the Enola Gay; I assume that a ticking-bomb hard-liner will not flinch from this conclusion. But at this point, we verge on declaring all military threats and adversaries that menace American civilians to be ticking bombs whose defeat justifies torture. The limitation of torture to emergency exceptions, implicit in the ticking-bomb story, now threatens to unravel, making torture a legitimate instrument of military policy. And then the question becomes inevitable: Why not torture in pursuit of any worthwhile goal? 
5. Indeed, if you are willing to torture forty-nine innocent people to get information from the one who has it, why stop there? If suspects will not break under torture, why not torture their loved ones in front of them? They are no more innocent than the forty-nine you have already shown you are prepared to torture. In fact, if only the numbers matter, torturing loved ones is almost a no-brainer if you think it will work. Of course, you won't know until you try whether torturing his child will break the suspect. But that just changes the odds; it does not alter the argument.

The point of the examples is that in a world of uncertainty and imperfect knowledge, the ticking-bomb scenario should not form the point of reference. The ticking bomb is the picture that bewitches us. The real debate is not between one guilty man's pain and hundreds of innocent lives. It is the debate between the certainty of anguish and the mere possibility of learning something vital and saving lives. And, above all, it is the question about whether a responsible citizen must unblinkingly think the unthinkable and accept that the morality of torture should be decided purely by totaling up costs and benefits. ${ }^{47}$ Once you accept that only the numbers count, then anything, no matter how gruesome, becomes possible. "Consequentialist rationality," as Bernard Williams notes sardonically, "will have something to say even on the difference between massacring seven million, and massacring seven million and one." ${ }^{48}$

I am inclined to think that the path of wisdom instead lies in Holocaust survivor David Rousset's famous caution that normal human beings do not know that everything is possible. ${ }^{49}$ As Williams says, "there are certain situations so monstrous that the idea that the processes of moral rationality could yield an answer in them is insane" and "to spend time thinking what one would de-

\footnotetext{
${ }^{47}$ For a powerful version of the consequentialist argument, which acknowledges these consequences and accepts them (at least for dialectical purposes), see Louis Michael Seidman, Torture's Truth, 72 U. Chi. L. Rev. 881 (2005).

${ }^{48}$ Bernard Williams, A critique of utilitariamsm, in J.J.C. Smart \& Bernard Williams, Utilitarianism: for and against 75, 93 (1973).

${ }^{49}$ David Rousset, The Other Kingdom 168 (Ramon Guthrie trans., Howard Fertig, Inc. 1982).
} 
cide if one were in such a situation is also insane, if not merely frivolous." 50

\section{TORTURE AS A PRACTICE}

There is a second, insidious, error built into the ticking-bomb hypothetical. It assumes a single, ad hoc decision about whether to torture, by officials who ordinarily would do no such thing except in a desperate emergency. But in the real world of interrogations, decisions are not made one-off. The real world is a world of policies, guidelines, and directives. It is a world of practices, not of ad hoc emergency measures. Therefore, any responsible discussion of torture must address the practice of torture, not the ticking-bomb hypothetical. I am not saying anything original here; other writers have made exactly this point. ${ }^{51}$ But somehow, we always manage to forget this and circle back to the ticking time bomb. Its rhetorical power has made it indispensable to the sensitive liberal soul, and we would much rather talk about the ticking bomb than about torture as an organized social practice.

Treating torture as a practice rather than as a desperate improvisation in an emergency means changing the subject from the ticking bomb to other issues like these: Should we create a professional cadre of trained torturers? That means a group of interrogators who know the techniques, who learn to overcome their instinctive revulsion against causing physical pain, and who acquire the legendary surgeon's arrogance about their own infallibility. It has happened before. Medieval executioners were schooled in the arts of agony as part of the trade: how to break men on the wheel, how to rack them, and even how to surreptitiously strangle them as an act of mercy without the bloodthirsty crowd catching on. ${ }^{52}$ In Louis XVI's Paris, torture was a hereditary family trade whose tricks were passed on from father to son. ${ }^{53}$ Who will teach torture tech-

\footnotetext{
${ }^{50}$ Williams, supra note 48 , at 92 . Williams suggests "that the unthinkable was itself a moral category." Id.

${ }^{51}$ See, e.g., Bowden, supra note 46, at 74, 76; Michael Ignatieff, The Torture Wars, New Republic, Apr. 22, 2002, at 40, 40; Marcy Strauss, Torture, 48 N.Y.L. Sch. L. Rev. 201, 270-71 (2003).

${ }^{52}$ Arthur Isak Applbaum, Professional Detachment: The Executioner of Paris, 109 Harv. L. Rev. 458, 459-60, 475 (1995).

${ }^{53}$ Id. at 459.
} 
niques now? Should universities create an undergraduate course in torture? Or should the subject be offered only in police and military academies? ${ }^{54}$ Do we want federal grants for research to devise new and better techniques? Patents issued on high-tech torture devices? Companies competing to manufacture them? Trade conventions in Las Vegas? Should there be a medical sub-specialty of torture doctors, who ensure that captives do not die before they talk ${ }^{55}$ The questions amount to this: Do we really want to create a torture culture and the kind of people who inhabit it? The ticking time bomb distracts us from the real issue, which is not about emergencies, but about the normalization of torture.

Perhaps the solution is to keep the practice of torture secret in order to avoid the moral corruption that comes from creating a public culture of torture. But this so-called "solution" does not reject the normalization of torture. It accepts it, but layers on top of it the normalization of state secrecy. The result would be a shadow culture of torturers and those who train and support them, operating outside the public eye and accountable only to other insiders of the torture culture.

Just as importantly: Who guarantees that case-hardened torturers, inured to levels of violence and pain that would make ordinary people vomit at the sight, will know where to draw the line on when torture should be used? They rarely have in the past. They didn't in Algeria. ${ }^{56}$ They didn't in Israel, where in 1999, the Israeli Supreme Court backpedaled from an earlier consent to torture lite

\footnotetext{
${ }^{54}$ We should recall that for years American instructors taught torture to Latin American military officers at the School of the Americas in Fort Benning, Georgia. See Dana Priest, U.S. Instructed Latins On Executions, Torture, Wash. Post, Sept. 21, 1996, at A1.

${ }^{55}$ Summarizing extensive studies by researchers, Jean Maria Arrigo notes medical participation in $20 \%$ to $40 \%$ of torture cases. One study, a random survey of 4,000 members of the Indian Medical Association (of whom 743 responded), revealed that " $58 \%$ believed torture interrogation permissible; $71 \%$ had come across a case of probable torture; $18 \%$ knew of health professionals who had participated in torture; $16 \%$ had witnessed torture themselves; and $10 \%$ agreed that false medical and autopsy reports were sometimes justified." Jean Maria Arrigo, A Consequentialist Argument against Torture Interrogation of Terrorists (Jan. 30-31, 2003), at http://www.atlas.usafa.af.mil/jscope/JSCOPE03/Arrigo03.html.

${ }_{56}$ This is the conclusion Michael Ignatieff draws from the memoirs of French torturer Paul Aussaresses, who remains completely unapologetic for torturing and killing numerous Algerian terrorists. Ignatieff, supra note 51, at 42.
} 
because the interrogators were running amok and torturing twothirds of their Palestinian captives. ${ }^{57}$ In the Argentinian Dirty War, the tortures began because terrorist cells had a policy of fleeing when one of their members had disappeared for forty-eight hours, leaving authorities two days to wring the information out of the captive. $^{58}$ Mark Osiel, who has studied the Argentinean military in the Dirty War, reports that many of the torturers initially had qualms about what they were doing, until their priests reassured them that they were fighting God's fight. ${ }^{59} \mathrm{By}$ the end of the Dirty War, the qualms were gone, and, as John Simpson and Jana Bennett report, hardened young officers were placing bets on who could kidnap the prettiest girl to rape and torture. ${ }^{60}$ Escalation is the rule, not the aberration. ${ }^{61}$

There are two fundamental reasons for this: one rooted in the nature of bureaucracy and the other in social psychology. The liberal ideology of torture presupposes a torturer impelled by the desire to stop a looming catastrophe, not by cruelty. Implicitly, this image presumes that the interrogator and the decisionmaker are the same person. But the defining fact about real organizations is the division of labor. The person who decides whether this prisoner presents a genuine ticking-bomb case is not the interrogator. The decision about what counts as a ticking-bomb case-one where torture is the lesser evil-depends on complex value judgments, and these are made further up the chain of command. The interrogator simply executes decisions made elsewhere.

Interrogators do not inhabit a world of loving kindness, or of equal concern and respect for all human beings. Interrogating resistant prisoners non-violently and non-abusively still requires a relationship that in any other context would be morally abhorrent. It requires tricking information out of the subject, and the interrogator does this by setting up elaborate scenarios to disorient the subject and propel him into an alternative reality. The subject must be

${ }^{57}$ Bowden, supra note 46 , at 74-76.

${ }^{58}$ Mark J. Osiel, Mass Atrocity, Ordinary Evil, and Hannah Arendt: Criminal Consciousness in Argentina's Dirty War 40 (2002).

${ }^{59}$ Id. at $120-21$.

${ }^{60}$ John Simpson \& Jana Bennett, The Disappeared and the Mothers of the Plaza: The Story of the 11,000 Argentinians Who Vanished 109 (1985).

${ }^{61}$ Ignatieff, supra note 51 , at 42. 
deceived into thinking that his high-value intelligence has already been revealed by someone else, so that it is no longer of any value. He must be fooled into thinking that his friends have betrayed him or that the interrogator is his friend. The interrogator disrupts his sense of time and place, disorients him with sessions that never take place at predictable times or intervals, and manipulates his emotions. The very names of interrogation techniques show this: "Emotional Love," "Emotional Hate," "Fear Up Harsh," "Fear Up Mild," "Reduced Fear," "Pride and Ego Up," "Pride and Ego Down," "Futility." make the subject think he is in the clutches of a much-feared secret police organization from a different country ("False Flag"). Every bit of the subject's environment is fair game for manipulation and deception, as the interrogator aims to create the total lie that gets the subject talking. ${ }^{63}$

Let me be clear that I am not objecting to these deceptions. None of these practices rises to the level of abuse or torture lite, let alone torture heavy, and surely tricking the subject into talking is legitimate if the goals of the interrogation are legitimate. But what I have described is a relationship of totalitarian mind-control more profound than the world of Orwell's 1984. The interrogator is like Descartes' Evil Deceiver, and the subject lives in a false reality reminiscent of The Matrix. The liberal fiction that interrogation can be done by people who are neither cruel nor tyrannical runs aground on the fact that regardless of the interrogator's character off the job, on the job, every fiber of his concentration is devoted to dominating the mind of the subject.

Only one thing prevents this from turning into abuse and torture, and that is a clear set of bright-line rules, drummed into the interrogator with the intensity of a religious indoctrination, complete with warnings of fire and brimstone. American interrogator Chris Mackey reports that warnings about the dire consequences of violating the Geneva Conventions "were repeated so often that by

\footnotetext{
${ }^{62}$ Schlesinger Report, supra note 39, at 908, 966-67; see also Chris Mackey \& Greg Miller, The Interrogator's War: Inside the Secret War Against Al Qaeda 479-83 (2004).

${ }^{63}$ See Bowden, supra note 46 , at $64-65$.
} 
the end of our time at [training school] the three syllables 'Leaven-worth' were ringing in our ears."

But what happens when the line is breached? When, as in Afghanistan, the interrogator gets mixed messages about whether Geneva applies, or hears rumors of ghost detainees, of high-value captives held for years of interrogation in the top-secret facility known as "Hotel California," located in some nation somewhere?" Or when the interrogator observes around him the move from deception to abuse, from abuse to torture lite, from torture lite to beatings and waterboarding? Without clear lines, the tyranny innate in the interrogator's job has nothing to hold it in check. ${ }^{66}$ Perhaps someone, somewhere in the chain of command, is wringing hands over whether this interrogation qualifies as a ticking-bomb case; but the interrogator knows only that the rules of the road have changed and the posted speed limits no longer apply. The liberal fiction of the conscientious interrogator overlooks a division of moral labor in which the person with the fastidious conscience and the person doing the interrogation are not the same.

The fiction must presume, therefore, that the interrogator operates only under the strictest supervision, in a chain of command where his every move gets vetted and controlled by the superiors

\footnotetext{
${ }^{64}$ Mackey \& Miller, supra note 62 , at 31 .

${ }^{65}$ Toby Harnden, Welcome to the CIA's Hotel California, Daily Telegraph (London), Mar. 4, 2003, at 11 (describing a secret interrogation center named for an Eagles song because "you can check in any time, but you can never leave").

${ }^{66}$ This point is made in the Fay-Jones Report on Abu Ghraib. After noting that conflicting directives about stripping prisoners and using dogs were floating around simultaneously, the Report adds:

Furthermore, some military intelligence personnel executing their interrogation duties at Abu Ghraib had previously served as interrogators in other theaters of operation, primarily Afghanistan and GTMO. These prior interrogation experiences complicated understanding at the interrogator level. The extent of "word of mouth" techniques that were passed to the interrogators in Abu Ghraib by assistance teams from Guantanamo, Fort Huachuca, or ainongst themselves due to prior assignments is unclear and likely impossible to definitively determine. The clear thread in the CJTF-7 policy memos and published doctrine is the humane treatment of detainees and the applicability of the Geneva Conventions. Experienced interrogators will confirm that interrogation is an art, not a science, and knowing the limits of authority is crucial. Therefore, the existence of confusing and inconsistent interrogation technique policies contributed to the belief that additional interrogation techniques were condoned in order to gain intelligence.
}

Fay-Jones Report, supra note 22, at 987, 1004. 
who are actually doing the deliberating. The trouble is that this assumption flies in the face of everything that we know about how organizations work. The basic rule in every bureaucratic organization is that operational details and the guilty knowledge that goes with them get pushed down the chain of command as far as possible. As sociologist Robert Jackall explains,

[i]t is characteristic ... that details are pushed down and credit is pulled up. Superiors do not like to give detailed instructions to subordinates.... [O]ne of the privileges of authority is the divestment of humdrum intricacies.... Perhaps more important, pushing details down protects the privilege of authority to declare that a mistake has been made.... Moreover, pushing down details relieves superiors of the burden of too much knowledge, particularly guilty knowledge. ${ }^{67}$

We saw this phenomenon at Abu Ghraib, where military intelligence officers gave military police vague orders like: “'Loosen this guy up for us;' 'Make sure he has a bad night.' 'Make sure he gets the treatment." 68 Suppose that the eighteen-year-old guard interprets " $[\mathrm{m}]$ ake sure he has a bad night" to mean, simply, "keep him awake all night." How do you do that without physical abuse? ${ }^{69}$ Furthermore, personnel at Abu Ghraib witnessed far harsher treatment of prisoners by "other governmental agencies" (OGA), a euphemism for the Central Intelligence Agency. They saw OGA spirit away the dead body of an interrogation subject, and allegedly witnessed a contract employee rape a youthful prisoner. ${ }^{71}$ When

${ }^{67}$ Robert Jackall, Moral Mazes: The World of Corporate Managers 20 (1988).

${ }^{68}$ Seymour M. Hersh, Chain of Command: The Road from 9/11 to Abu Ghraib 30 (2004).

${ }^{69}$ As a military police captain told Hersh, "when you ask an eighteen-year-old kid to keep someone awake, and he doesn't know how to do it, he's going to get creative." Id. at 34.

${ }^{70}$ See Fay-Jones Report, supra note 22, at 987, 990 ("Working alongside non-DOD organizations/agencies in detention facilities proved complex and demanding. The perception that non-DOD agencies had different rules regarding interrogation and detention operations was evident. ... The appointing authority and investigating officers made a specific finding regarding the issue of 'ghost detainees' within Abu Ghraib. It is clear that the interrogation practices of other government agencies led to a loss of accountability at Abu Ghraib.").

${ }^{71}$ Hersh, supra note 68 , at $44-45$. 
that is what you see, abuses like those in the Abu Ghraib photos will not look outrageous. Outrageous compared with what?

This brings me to the point of social psychology. Simply stated, it is this: we judge right and wrong against the baseline of whatever we have come to consider "normal" behavior, and if the norm shifts in the direction of violence, we will come to tolerate and accept violence as a normal response. The psychological mechanisms for this re-normalization have been studied for more than half a century, and by now they are reasonably well understood..$^{2}$ Rather than detour into psychological theory, however, I will illustrate the point with the most salient example-one that seems so obviously applicable to Abu Ghraib that the Schlesinger Commission discussed it at length in an appendix to its report. ${ }^{73}$ This is the famous Stanford Prison Experiment. Male volunteers were divided randomly into two groups who would simulate the guards and inmates in a mock prison. Within a matter of days, the inmates began acting like actual prison inmates - depressed, enraged, and anxious. And the guards began to abuse the inmates to such an alarming degree that the researchers had to halt the two-week experiment after just seven days. In the words of the experimenters:

The use of power was self-aggrandising and self-perpetuating. The guard power, derived initially from an arbitrary label, was intensified whenever there was any perceived threat by the prisoners and this new level subsequently became the baseline from which further hostility and harassment would begin.... [T]he absolute level of aggression as well as the more subtle and "creative" forms of aggression manifested, increased in a spiralling function. ${ }^{74}$

${ }^{72}$ For details, see David Luban, The Ethics of Wrongful Obedience, in Ethics in Practice: Lawyers' Roles, Responsibilities, and Regulation 94, 101-03 (Deborah L. Rhode ed., 2000); David Luban, Integrity: Its Causes and Cures, 72 Fordham L. Rev. 279, 293-98 (2003).

${ }_{73}^{73}$ Schlesinger Report, supra note 39 , at 908, 970-71.

${ }^{74}$ Craig Haney et al., Interpersonal Dynamics of a Simulated Prison, 1 Int'l. J. Criminology \& Penology 69, 94 (1973); see also Philip G. Zimbardo et al., The Mind is a Formidable Jailer: A Pirandellian Prison, N.Y. Times Mag., Apr. 8, 1973, at $40-42$ and the remarkable internet slide-show of the experiment, Philip G. Zimbardo, Stanford Prison Experiment: A Simulation Study of the Psychology of Imprisonment Conducted at Stanford University (1999), at http://www.prisonexp.org. 
It took only five days before a guard, who prior to the experiment described himself as a pacifist, was forcing greasy sausages down the throat of a prisoner who refused to eat; and in less than a week, the guards were placing bags over prisoners' heads, making them strip, and sexually humiliating them in ways reminiscent of $\mathrm{Abu}$ Ghraib. $^{75}$

My conclusion is very simple. Abu Ghraib is the fully predictable image of what a torture culture looks like. Abu Ghraib is not a few bad apples-it is the apple tree. And you cannot reasonably expect that interrogators in a torture culture will be the fastidious and well-meaning torturers that the liberal ideology fantasizes.

This is why Alan Dershowitz has argued that judges, not torturers, should oversee the permission to torture, which in his view must be regulated by warrants. The irony is that Jay S. Bybee, who signed the Justice Department's highly permissive torture memo, is now a federal judge. Politicians pick judges, and if the politicians accept torture, the judges will as well. Once we create a torture culture, only the naive would suppose that judges will provide a safeguard. Judges do not fight their culture-they reflect it.

For all these reasons, the ticking-bomb scenario is an intellectual fraud. In its place, we must address the real questions about torture-questions about uncertainty, questions about the morality of consequences, and questions about what it does to a culture and the torturers themselves to introduce the practice. Once we do so, I suspect that few Americans will be willing to accept that everything is possible.

\section{The Construction of A TORTURe Culture: The TORTURE LAWYERS OF WASHINGTON}

A skeptic might respond that my dire warnings about a torture culture are exaggerated, overwrought, and (above all) hypothetical. Would that it were so. As a coda to the argument I have presented, I wish to offer a case study of a torture culture constructed

${ }^{75}$ John Schwartz, Simulated Prison in '71 Showed a Fine Line Between 'Normal' and 'Monster,' N.Y. Times, May 6, 2004, at A20; Zimbardo, supra note 74, at slides 8, $18,21,28,33$. The sausage incident is described in Craig Haney \& Philip G. Zimbardo, The Socialization into Criminality: On Becoming a Prisoner and a Guard, in Law, Justice, and the Individual in Society: Psychological and Legal Issues 198, 209 (June Louin Tapp \& Felice J. Levine eds., 1977). 
under our noses in Washington. I am referring to the group of lawyers in President George W. Bush's administration who wrote the highly-permissive secret memoranda that came close to legitimizing torture for interrogation purposes. These lawyers illustrate as graphically as any group how quickly and easily a secret culture of torture supporters can emerge even in the heart of a liberal culture. They illustrate as well how readily the liberal ideology of torture transforms into something far removed from liberalism.

By now, the background is well known, but it may be worthwhile to recapitulate briefly. There were, in reality, over a dozen memoranda pertaining to the status and treatment of detainees circulated between the White House, the Department of Defense, the State Department, and the Justice Department. ${ }^{76}$ The most controversial, though, emerged from the Office of Legal Counsel in the Justice Department ("OLC"). Two OLC memos, written in early 2002, concluded that the Geneva Conventions do not cover al Qaeda or Taliban captives. ${ }^{77}$ These set the stage for President Bush's February 7,2002, memo affirming that conclusion, and asserting that prisoners would be treated consistently with Geneva "to the extent appropriate and consistent with military necessity"-a large loophole for intelligence-gathering. ${ }^{78}$ In effect, the President, relying on

${ }^{76}$ Many are included in Torture Papers, supra note 10 . But they are still coming out. The New Yorker posted several new memoranda on February 8, 2005, in conjunction with an article on the "outsourcing" of torture. The Torture Debate, The New Yorker, Feb. 8, 2005, at http://www.newyorker.com/online/content/ ?050214on_onlineonly02; Jane Mayer, Outsourcing Torture, The New Yorker, Feb. 14 \& 21, 2005, at 106.

${ }^{77}$ Draft Memorandum from John Yoo, Deputy Assistant Attorney Gen., U.S. Dept. of Justice Office of Legal Counsel, and Robert J. Delabunty, Special Counsel, U.S. Dept. of Justice Office of Legal Counsel, to William J. Haynes II, Gen. Counsel, Dept. of Def. (Jan. 9, 2002), in Torture Papers, supra note 10, at 38, 38; Memorandum from Jay S. Bybee, Assistant Attorney General, U.S. Dept. of Justice Office of Legal Counsel, to Alberto R. Gonzales, Counsel to the President, and William J. Haynes II, General Counsel, Dep't of Defense (Jan. 22, 2002), in Torture Papers, supra note 10, at 81,81 . In July 2005, the D.C. Court of Appeals endorsed this view in Hamdan v. Rumsfeld, 415 F.3d 33, 40-42 (D.C. Cir. 2005), concluding that Article 3 of the Geneva Conventions does not apply to al Qaeda captives. Article 3, which is identical in the four Geneva Conventions, provides basic human rights, including the right not to be subjected to cruel, humiliating, or degrading treatment, to prisoners who do not qualify for full Geneva protection.

${ }_{78}^{78}$ Memorandum from President George W. Bush to the Vice President et al. (Feb. 7, 2002), in Torture Papers, supra note I0, at 134, 135. A second loophole is that 
the OLC, proclaimed that if military necessity requires it, Geneva is gone.

Six months later, OLC tendered another memo, this one on the question of whether harsh interrogation tactics violate U.S. obligations under the Torture Convention and its implementing statutes. This memo, drafted in part by Professor John Yoo and signed by OLC head Jay S. Bybee, reached a series of startling conclusions: that the infliction of pain rises to the level of torture only if the pain is as severe as that accompanying "death, organ failure, or serious impairment of body functions;" logical pain rises to the level of torture only if the interrogator specifically intended it to cause "lasting... damage" such as posttraumatic stress disorder, ${ }^{80}$ that it would be unconstitutional to apply anti-torture laws to interrogations authorized by the President in the War on Terror; ${ }^{81}$ and that, "under the current circumstances, necessity or self-defense may justify interrogation methods that might violate" the criminal prohibition on torture. ${ }^{82}$

The Bybee Memo proved to be enormously influential. In January 2003, Defense Secretary Donald Rumsfeld formed a working group on interrogation techniques, which produced its own report in April. ${ }^{83}$ Significantly, the working-group report was based substantially on the Bybee Memo, and in fact, incorporated portions of it verbatim. The working-group report, in turn, influenced policy on interrogation tactics. Two months after the Bybee Memorandum, a Defense Department lawyer, Lieutenant Colonel Diane Beaver, produced a memo of her own that legitimized harsh interrogational tactics, including " $[\mathrm{t}]$ he use of a wet towel to induce the

President Bush declared only that "the United States Armed Forces shall continue to treat detainees humanely." Id. The President's declaration does not cover the CIA.

${ }^{79}$ Memorandum from John C. Yoo, Deputy Assistant Attorney Gen., U.S. Dept. of Justice Office of Legal Counsel, to Alberto R. Gonzales, Counsel to the President (Aug. 1, 2002), in Torture Papers, supra note 10, at 172, 176 [hereinafter Bybee Memo].

${ }^{80}$ Id. at 177.

${ }^{81}$ Id. at 173 .

${ }^{82}$ Id.

${ }^{83}$ U.S. Dept. of Defense, Working Group Report on Detainee Interrogations in the Global War on Terrorism: Assessment of Legal, Historical, Policy and Operational Considerations (Apr. 4, 2003), in Torture Papers, supra note 10, at 286. 
misperception of suffocation," provided that there is a legitimate national security objective. ${ }^{84}$

None of these memoranda and reports were produced in a vacuum. The Bybee Memorandum "was vetted by a larger number of officials, including lawyers at the National Security Council, the White House counsel's office, and Vice President Cheney's office." ${ }^{, 5}$ Apparently, then-White House counsel Alberto Gonzales requested the memorandum. ${ }^{86}$ And the Department of Defense working group was formed after the head of an Army interrogation team requested permission to escalate to harsher tactics. ${ }^{87}$

Once they were leaked, the OLC memoranda proved to be incredibly controversial, not only because of their conclusions, but because of a near consensus that the legal analysis in the Bybee Memo was bizarre. The memo argued that because a health-care statute lists severe pain as a possible symptom of a medical emergency, only pain equivalent to that accompanying medical emergencies is severe. ${ }^{88}$ It attempted to show that while the necessity defense applies to torture, it need not apply to life-saving abortions. It also argued that Congress had defined torture so as to permit its use when necessary, even though Congress categorically forbade torture regardless of its purpose. ${ }^{89}$ And it argued that the President has authority to order torture regardless of the statutory prohibition, without bothering to so much as raise the question whether this runs contrary to the Take Care Clause of the Constitution. ${ }^{90}$ It is hard not to agree with Peter Brooks's blunt assessment: the Bybee Memo "offers a remarkable example of textual interpretation run amok-less 'lawyering as usual' than the work of some bizarre

${ }^{84}$ Memorandum from Diane E. Beaver, Staff Judge Advocate, to Dept. of Defense Joint Task Force (Oct. 11, 2002), in Torture Papers, supra note 10, at 229, 235.

${ }^{85}$ Priest, supra note 38 , at A1.

${ }^{86}$ See David Johnston \& Neil A. Lewis, Bush's Counsel Sought Ruling About Torture, N.Y. Times, Jan. 5, 2005, at A1; R. Jeffrey Smith \& Dan Eggen, Gonzales Helped Set the Course for Detainees, Wash. Post, Jan. 5, 2005, at A1.

${ }^{87}$ Press Briefing by White House Counsel Judge Alberto Gonzales, DOD General Counsel William Haynes, DOD Deputy Gen. Counsel Daniel Dell'Orto and Army Deputy Chief of Staff for Intelligence Gen. Keith Alexander (June 22, 2004), at http://www.whitehouse.gov/news/releases/2004/06/20040611-14.html.

${ }^{8}$ Bybee Memo, supra note 79, at 172, 176.

${ }^{89}$ Id. at 209,209 n.23.

${ }^{90}$ The Take Care Clause requires that the President "shall take Care that the Laws be faithfully executed." U.S. Const. art. II, § 3 . 
literary deconstructionist." ${ }^{91}$ Unsurprisingly, in the wake of the Abu Ghraib scandal, the Justice Department repudiated the Bybee Memo. Indeed, former OLC lawyers from past Republican administrations criticized the memo, and Ruth Wedgwood, perhaps the most prominent academic defender of Bush Administration legal positions in the War on Terror, denounced the Bybee Memo in a blistering Wall Street Journal op-ed, which she co-authored with former CIA Director R. James Woolsey. ${ }^{92}$ Shortly before Alberto Gonzales faced confirmation hearings as Attorney General, the OLC issued a new torture memorandum (the "Levin Memorandum"), repudiating and replacing the Bybee Memo. It was posted unannounced on the Department of Justice's website, on December $30,2004 .^{93}$

What should we make of this? Not much, some might say. The Justice Department has disowned the Bybee Memo, Mr. Bybee has been promoted out of the OLC to the federal appellate bench, and Professor Yoo, the principal author of the Bybee Memo, has left government service. One way to understand the Bybee Memo is that it represents an odd moment when several stars and planets fell into an unusual alignment and the moonshine threw the OLC into a peculiarly aggressive mood. Now, however, the OLC has officially rescinded the Bybee Memo and replaced it with a document that begins with a ringing affirmation of U.S. opposition to torture. $^{94}$

But the lawyers' torture culture is not just the OLC in an isolated period of time, now past. It would be a dramatic mistake to suppose that the Justice Department has abandoned its views merely because it has disowned the Bybee Memo. Although the Levin Memo condemns torture and repudiates the Bybee Memo's narrow definition of "severe pain," a careful reading shows that it does not broaden it substantially. Stunningly, all its illustrative ex-

\footnotetext{
${ }^{91}$ Peter Brooks, The Plain Meaning of Torture?, Slate, Feb. 9, 2005, at http://www.slate.com/id/2113314.

${ }^{22}$ Ruth Wedgwood \& R. James Woolsey, Law and Torture, Wall St. J., June 28, 2004, at A10.

${ }^{93}$ Memorandum from Daniel Levin, Acting Assistant Attorney Gen., U.S. Dept. of Justice Office of Legal Counsel, to James B. Comey, Deputy Attorney Gen. (Dec. 30, 2004), at http://www.usdoj.gov/olc/dagmemo.pdf [hereinafter Levin Memo].

${ }^{94}$ The Levin Memo begins: "Torture is abhorrent both to American law and values and to international norms." $1 d$. at 1.
} 
amples of "the nature of the extreme conduct that falls within the statutory definition" of torture are on the upper end of the scale of barbarism." They include, for example, "severe beatings to the genitals, head, and other parts of the body with metal pipes, brass knuckles, batons, a baseball bat, and various other items; removal of teeth with pliers ... cutting off ... fingers, pulling out ... fingernails" and similar atrocities. ${ }^{96}$ Levin includes no hint that torture lite, or even torture medium, are prohibited by the statute. The Levin Memo's analysis of "severe mental pain" differs from that of the Bybee Memo in that it no longer suggests that the term encompasses only psychological damage that lasts for months or even years. Again, however, its illustrative examples all involve damage that lasted for years." Nor does Levin criticize the Bybee Memo's analyses of self-defense or necessity; it simply declines to discuss defenses. Similarly, it leaves open the question of whether the President can authorize torture, declaring evasively that because this President opposes torture, any discussion of the limits of his authority is unnecessary. ${ }^{98}$ The Levin Memo does acknowledge that techniques causing "severe physical suffering" count as torture even if they do not cause "severe physical pain"-and that may rule out some stress positions that the Bybee Memo permits." But apart from this one change, the Levin Memo represents the minimum possible cosmetic emendation of the Bybee Memo. It retracts only the arguments that journalists had jumped on (the "organ failure" defimition of torture and the excessive emphasis Bybee placed on the specific intent requirement), retains a conception of torture as atrocity fully in line with the liberal ideology, and evades the questions of criminal defenses and Presidential authority to authorize torture.

Indeed, the OLC prepared other opinions, never released or leaked, which addressed specific interrogation techniques-and the

\footnotetext{
${ }^{95}$ Id. at 10.

${ }^{96}$ Id.

${ }^{97}$ Compare the Levin Memo, id. at 14-15 (arguing that mental pain "must extend for some period of time"), with the Bybee Memo, supra note 79, at 172 (arguing that mental pain must be "of significant duration, e.g., lasting for months or even years").

${ }^{98}$ Levin Memo, supra note 93, at 2.

${ }^{99}$ Id. at 10.
} 
Levin Memo leaves these untouched. ${ }^{100}$ In December 2004, the Bush administration fought off restrictions (passed by a ninety-six to two Senate vote) which "would have explicitly extended to intelligence officers a prohibition against torture or inhumane treatment, and would have required the C.I.A. as well as the Pentagon to report to Congress about the methods they were using." ${ }^{101}$ When asked why the administration resisted these restrictions, both Alberto Gonzales and Condaleezza Rice replied that it was to deny protection to people who are not entitled to it. ${ }^{102}$ Neither finished the sentence: "not entitled to protection from torture or inhumane treatment."

One major loophole that the torture lawyers exploit is the distinction drawn in the Torture Convention between torture and "cruel, inhuman, or degrading" ("CID") treatment. ${ }^{103}$ The Convention bans both, but U.S.-implementing legislation criminalized only torture, not CID. ${ }^{104} \mathrm{Mr}$. Gonzales told the U.S. Senate in his written answers to questions that cruel, inhuman, and degrading treatment of detainees is forbidden to interrogators only within U.S. territory. ${ }^{105}$ The legal basis for this opinion was another piece of loop-

${ }^{100}$ The Levin Memo alludes to earlier opinions about the treatment of detainees and states that "we ... do not believe that any of their conclusions would be different under the standards set forth in this memorandum." Id. at 2 n.8. Although this passage refers to the "treatment of detainees" in general, rather than interrogation techniques in particular, we may infer that the earlier opinions concerned interrogation techniques because the subject of the opinions was whether the treatment in question violates the prohibition on torture. These approved techniques include waterboarding. Toni Locy \& John Diamond, Memo Lists Acceptable 'Aggressive' Interrogation Methods, USA Today, June 28, 2004, at A5.

${ }^{101}$ Douglas Jehl \& David Johnston, White House Fought New Curbs on Interrogations, Officials Say, N.Y. Times, Jan. 13, 2005, at A1.

${ }^{102}$ Gonzales's Responses to Durbin, supra note 21, at 7-8; Letter from Joshua B. Bolten, Dir., Office of Mgmt. and Budget, \& Condoleezza Rice, Assistant to the President for Nat'l Sec. Affairs, to Rep. Peter Hoekstra and Sen. Susan Collins 8-9 (Oct. 18, 2004), at http://www.fas.org/irp/news/2004/10/wh101804.pdf.

${ }^{103}$ Convention Against Torture, supra note 40, S. Treaty Doc. at 19, U.N.T.S at 113.

${ }^{104}$ Convention Against Torture and Other Cruel, Inhuman or Degrading Treatment or Punishment, S. Exec. Rep. No. 101-30, at 8, 25 (1990).

${ }^{105}$ Gonzales's Responses to Durbin, supra note 21, at 1-2; see also Letter from Senators Patrick Leahy, Dianne Feinstein, and Russel D. Feingold, to then-Attorney Gen. John Ashcroft (Jan. 25, 2005) (referring to Alberto Gonzales's written response to a Senate query on the extraterritorial permissibility of cruel, inhuman, or degrading treatment) (on file with the Virginia Law Review Association), and the detailed response, Letter from William E. Moschella, Assistant Attorney Gen., to Sen. Patrick J. 
hole lawyering on a par with the Bybee Memo. When the United States ratified the Torture Convention, it attached a reservation interpreting "cruel, inhuman, and degrading" treatment to mean treatment violative of the Fifth, Eighth, or Fourteenth Amendments. ${ }^{106}$ Because these amendments do not apply extraterritorially, Mr. Gonzales argued, the prohibition on CID does not bind U.S. interrogators abroad. Clearly, however, the Senate's reservation was referring to the substantive standards in the three amendments, not their jurisdictional scope. ${ }^{107}$ To read it as Mr. Gonzales does would attribute to the Senate the remarkably absurd proposition that by definition, nothing U.S. interrogators do abroad could ever be cruel, inhuman, or degrading.

It goes on. In March 2004, the OLC prepared a draft memorandum loopholing the Geneva Convention's prohibition on removing captives from the country of their capture and authorizing brief transfers of Iraqi captives out of Iraq for interrogation. ${ }^{108}$ In early 2005 , there were new revelations that the United States engages in "extraordinary renditions"-sending suspects for interrogation to states that engage in torture. ${ }^{109}$ Reportedly, secret legal opinions justify extraordinary renditions, which may violate the Torture Convention. ${ }^{110}$ In one well-known case, Maher Arar, a Canadian citizen of Syrian birth, was detained while transferring from one flight to another in New York City and sent to Syria, where he was tortured for a year. He is currently suing the U.S. government, which has moved to dismiss his suit on remarkable grounds, assert-

Leahy (Apr. 4, 2005) (spelling out in detail the legal basis for Mr. Gonzales's answer) (on file with the Virginia Law Review Association).

${ }^{106}$ Convention Against Torture, supra note 104, S. Exec. Rep. No. 101-30, at 29.

${ }^{107}$ The Senate has a long-standing practice of adding reservations to human rights treaties stipulating that the rights they grant are no broader than those the U.S. Constitution grants. The purpose of such reservations is to ensure that the treaties do not interfere with our domestic jurisprudence. Read in this normal way, the reservation simply ensures that the Convention Against Torture's meaning of "cruel" is the same as the Eighth Amendment's meaning.

${ }^{108}$ Draft Memorandum from Jack I. Goldsmith III, Assistant Attorney Gen., U.S. Dept. of Justice Office of Legal Counsel, to Alberto R. Gonzales, Counsel to the President (Mar. 19, 2004), in Torture Papers, supra note 10, at 366, 367-68.

${ }^{109}$ Mayer, supra note 76, at 106.

${ }^{110}$ Article 3 of the Torture Convention forbids the return of a person to "another State where there are substantial grounds for believing that he would be in danger of being subjected to torture." Convention Against Torture, supra note $40, \mathrm{~S}$. Treaty Doc. No. 100-20, at 6, 1465 U.N.T.S. at 114. 
ing that the facts needed to litigate his case are U.S. state secrets, and therefore he has no case. ${ }^{11}$ In another well-known case, Omar Abu Ali, a U.S. citizen of Saudi descent, was allegedly snatched by Saudi agents from his university classroom in Saudi Arabia, tortured, and detained for a year and a half at U.S. request. When his parents filed for habeas corpus, the government offered no rebuttal of their allegations, instead arguing that the court lacks jurisdiction, and grounding the government's action in the President's foreign affairs power (not even his commander-in-chief power). ${ }^{112}$

In April 2005, the circle beginning with the Abu Ghraib scandal closed, as a military investigation of alleged abuses at Guantanamo concluded that several of the humiliating techniques that drew shocked responses at Abu Ghraib-techniques such as sexually humiliating detainees, forcing them to wear women's underwear on their heads, leading them around on leashes, and forcing them to do dog tricks - are not illegal, and indeed have been authorized all along by Army Field Manual 34-52, the standard U.S. Army doctrine regarding interrogation. ${ }^{113}$ Along with this creative and unprecedented interpretation of Army doctrine, the report "found no evidence of torture or inhumane treatment at [Guantanamo]."114 Apparently, the Army no longer regards many of the Abu Ghraib techniques as "inhumane."

\section{CONCLUSION}

The only reasonable inference to draw from these recent efforts by the government to defend its actions is that the torture culture is

${ }^{111}$ Memorandum in Support of the United States' Assertion of State Secrets Privilege at 2-3, Arar v. Ashcroft, No. 04-CV-249-DGT-VVP (E.D.N.Y. Jan. 18, 2005) (on file with the Virginia Law Review Association).

${ }^{112}$ Abu Ali v. Ashcroft, 350 F. Supp. 2d 28, 31 (D.D.C. 2004). Judge Bates, an appointee of President George W. Bush, rejected the government's arguments with outrage. Id. at $40-41$.

${ }^{13}$ Army Regulation 15-6: Final Report: Investigation of FBI Allegations of Detainee Abuse at Guantanamo Bay, Cuba Detention Facility 8, 15-16, 19 (Apr. 1, 2005), available at http://www.globalsecurity.org/security/library/report/2005/ d20050714report.pdf. This report, based on investigations by Lt. Gen. Mark Schmidt and Brig. Gen. John Furlow, remains classified; the document cited here is an unclassified summary released on June 9, 2005.

${ }^{114}$ Id. at 1. 
still firmly in place, notwithstanding official condemnation of torture. Indeed, given that lawyers at the highest levels of government continue to loophole the laws against torture as energetically as ever, more than half a year after the Abu Ghraib revelations, the only reasonable inference to draw is that the United States government is currently engaging in brutal and humiliating interrogations. At most, torture has given way to CID. The persistence of interrogational brutality should surprise no one, because the liberal ideology of torture fully legitimizes it. The memos illustrate the ease with which arguments that pretend that torture can exist in liberal society, but only as an exception, quickly lead to erecting a torture culture, a network of institutions and practices that regularize the exception and make it standard operating procedure.

For this reason, the liberal ideology of torture, which assumes that torture can be neatly confined to exceptional ticking-bomb cases and surgically severed from cruelty and tyranny, represents a dangerous delusion. It becomes more dangerous still coupled with an endless war on terror, a permanent emergency in which the White House eagerly insists that its emergency powers rise above the limiting power of statutes and treaties. Claims to long-term emergency powers that entail the power to torture should send chills through liberals of the right as well as the left, and no one should still think that liberal torture has nothing to do with tyranny. 
